\title{
REGIONAL DISPARITIES IN THE DISTRIBUTION OF TOURISM EMPLOYEES IN THE SOUTHEAST DEVELOPMENT REGION
}

DOI: http://dx.doi.org/10.18509/GBP.2019.52

UDC: 331.5:338.48(4-12)

\author{
Jioță Oana-Elena ${ }^{1,2}$ \\ Pintilii Radu-Daniel ${ }^{1,2}$ \\ Marian Marin 1,2 \\ Gruia Karina ${ }^{1,2}$ \\ Grecu Alexandra ${ }^{1,2}$ \\ ${ }^{1}$ Research Center for Integrated Analysis and Territorial Management, \\ University of Bucharest, Romania \\ ${ }^{2}$ Faculty of Geography, University of Bucharest, Bucharest, Romania
}

\begin{abstract}
The tourism industry can play a particularly important role in the economic development of territorial systems that have tourism resources, through the human and material potential that can train it, but also by stimulating the development of the domains with which it interacts. One of the multiplier effects of tourism is job creation. They are created both directly by increasing the number of employees in the tourism field and indirectly in areas such as agriculture, construction or small producers. Tourism activities can thus help mitigate unemployment in areas where this economic activity is stimulated. In the present study we intend to analyze the way of distribution of the employees in tourism at the regional level for the period 2000-2016. In this respect, a database of employees from tourism was made for the period 2000-2016 at territorial administrative unit level, a database that was later used to represent the distribution of employees in a territorial profile at the level of the South East Development Region. On the whole, the number of employees in the field is significantly higher in the territorial systems with significant tourism resources, but it should be taken into account the seasonal degree of a fairly large number of jobs. However, we can say that tourism has a multiplication effect, superior to other economic areas, contributing to the increase of the revenues in the local economies.
\end{abstract}

Keywords: tourism, employees, regional disparities, development region

\section{INTRODUCTION}

Today, tourism is one of the most dynamic economic sectors in the world, capable of significant change both economically and socially [1], [2]. As a result of this influence, what can be exercised, tourism is considered a viable alternative for reducing the economic gaps and territorial disparities at the level of the regions that have tourism resources with the possibility of capitalizing [3], [4]. Among the advantages that result from the development of the tourism sector can be mentioned: efficient use of local resources, raising local community revenues, increasing employment, stimulating entrepreneurial initiative [5]. The importance of tourism for the world economy is highlighted by the WTO through several relevant figures: about $10 \%$ of the world's GDP and one from 10 jobs is due to tourism, aspects that show the increasingly important role that global tourism plays [6]. For the EU, tourism is an important economic activity, with three of the Member States (France, Spain and Italy) being top destinations worldwide 
[6]. In fact, Eurostat estimated in 2014 that 2.3 million businesses in the tourism sector were active at EU level, with around 12.3 million employees representing $21.5 \%$ of service sector [7]. From this perspective, the tourism sector can be an important employer, with employment being one of the benefits of developing tourist activities [8]. However, it should not be neglected that the workforce in the tourism sector is particularly important both in terms of quantity and quality, having a determining role in the economic performance of this economic sector [9]. Another aspect to be mentioned is that tourism development has been a priority for many local authorities, being considered a solution for the mitigation of unemployment where employment opportunities are few but tourism resources allow for its development [8].

\section{METHODOLOGY}

In the present study we intend to analyze the distribution of tourism employees at the level of the South East Development Region (Fig.1), one of the eight development regions existing in Romania. Within this region, there are six counties: Buzau, Vrancea, Galati, Brăila, Tulcea and Constanţa, having in terms of tourism, various tourist and natural resources, both natural and anthropic, some being specific as the Black Sea coast and the Danube Delta. Also, in the year 2018, the Southeast Region concentrated about $16 \%$ of the total tourist accommodation structures, accounting for approximately $46 \%$ of the existing national accommodation capacity [10]. In order to analyze the way of distribution of employees in tourism at the regional level, a database of the employees for tourism for the period 2000-2016 was made at the level of the territorial administrative unit, a database that was later used to make cartographic representations of territorial distribution of employees.

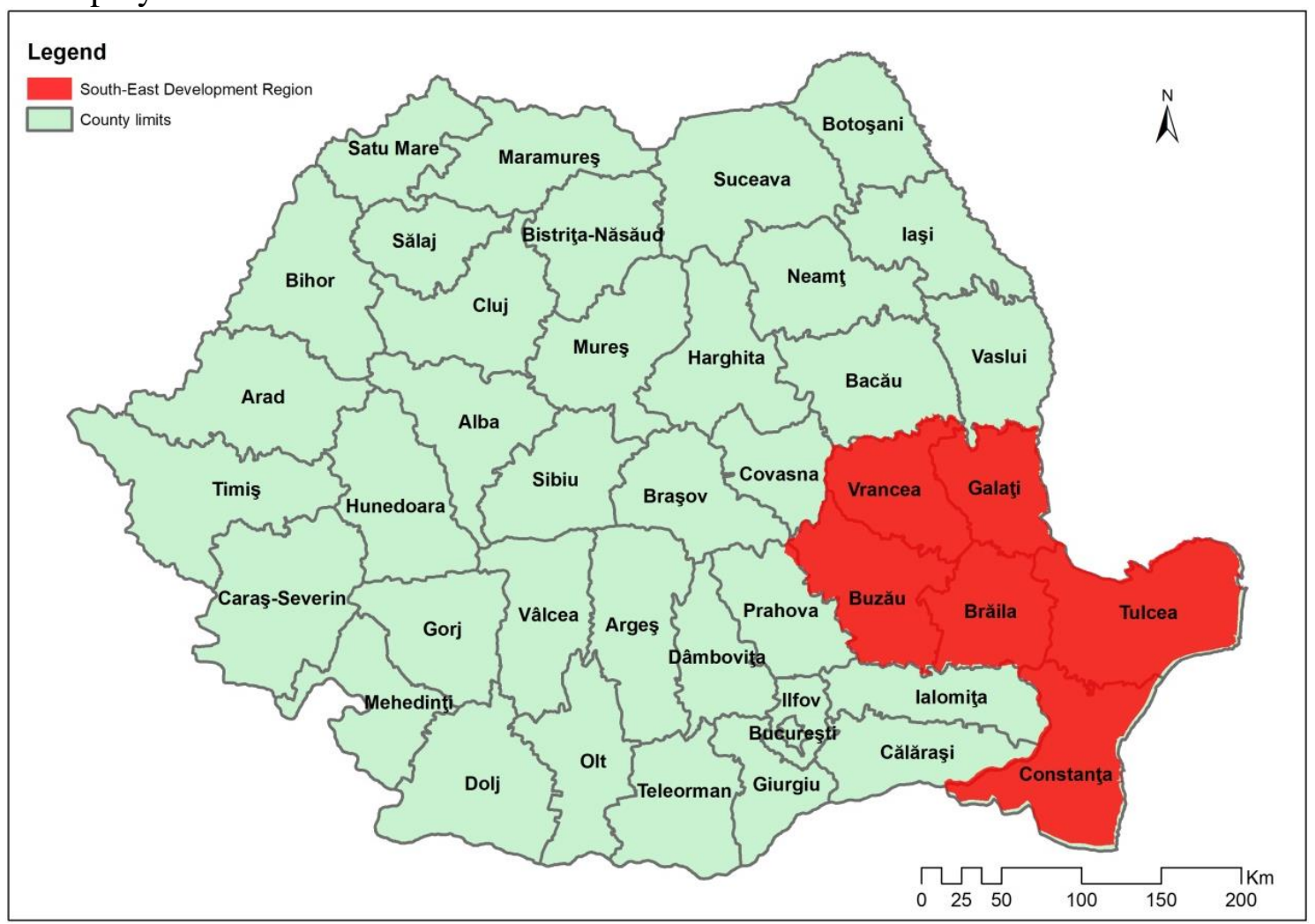

Figure 1. South East Development Region 


\section{RESULTS}

Regarding the spatial distribution of the number of employees in tourism within the Southeast Development Region, in the year 2000, there is an almost uniform distribution in the counties of Constanta, Tulcea and Buzau, in which tourist activities are well represented and a small number of localities with employees in the tourism field in the counties of Galaţi, Braila and Vrancea, in which agricultural and industrial activities predominate (Fig. 2). Out of the total of 165 territorial administrative units, $75 \%$ of them did not register tourism employees, the largest being in the counties of Galaţi and Braila. The territorial administrative units with the largest number of employees are Constanta and Mangalia with about 2,000 employees each.

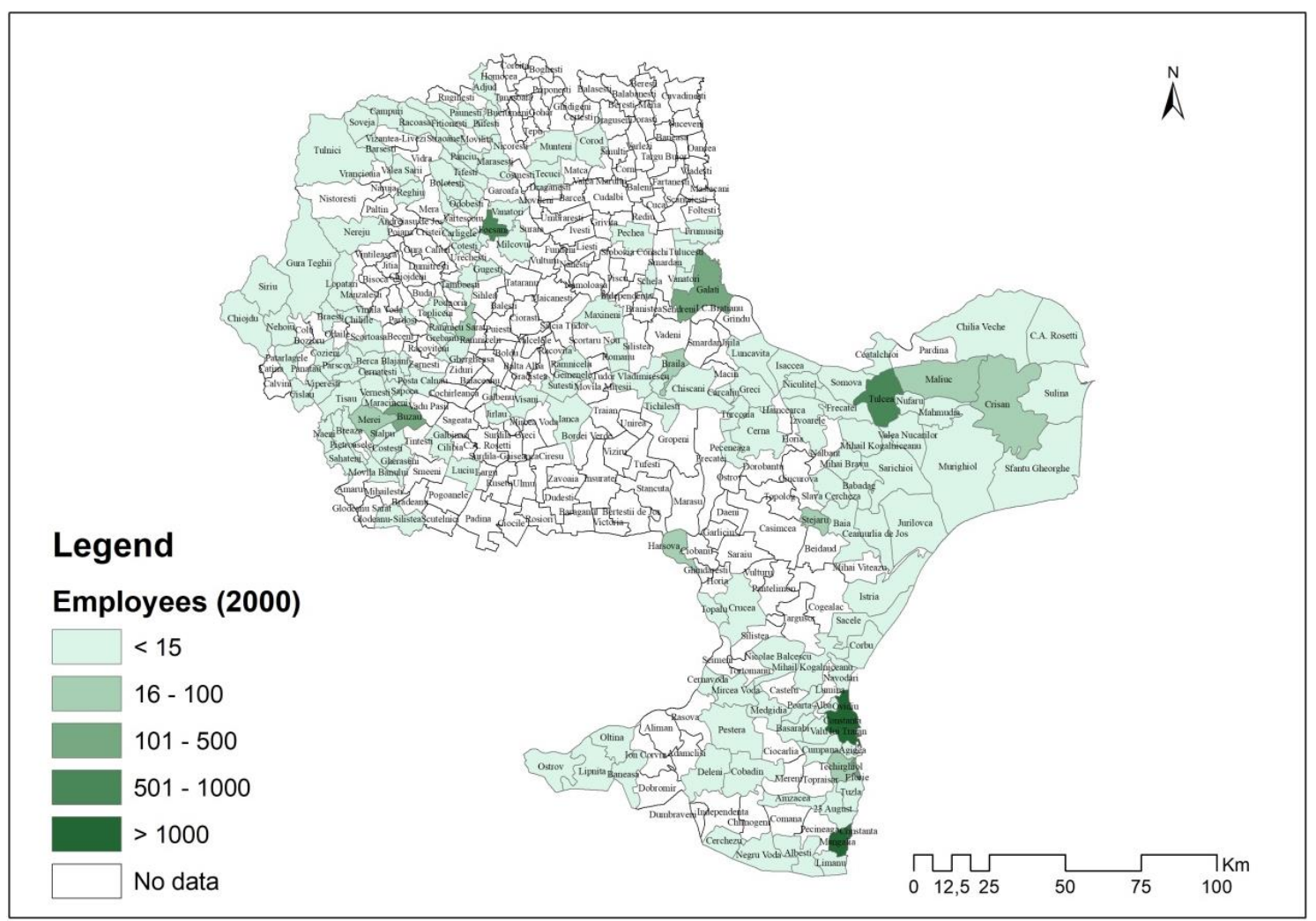

Figure 2. Distribution of the number of employees at the level of the South East Development Region in 2000

For the year 2008 (Fig. 3), the number of employees in the tourist field increases, only $48 \%$ of the administrative-territorial units do not register employees in the field of tourism. There are several localities in the Danube Delta area (Murighiol, Sulina, Jurilovca, Somova) in Constanta County (Mihail Kogalniceanu, Năvodari, Cobadin, Limanu) and Buzău County (Berca, Vipereşti, Poșta Câlnău). This increase in the number of employees can be attributed to the development of some older tourist destinations, for example the 2 Mai and Vama Veche, located within Limanu commune, Constanta County. The Danube Delta is also becoming more attractive as a tourist destination through its investments in 2000-2008. 


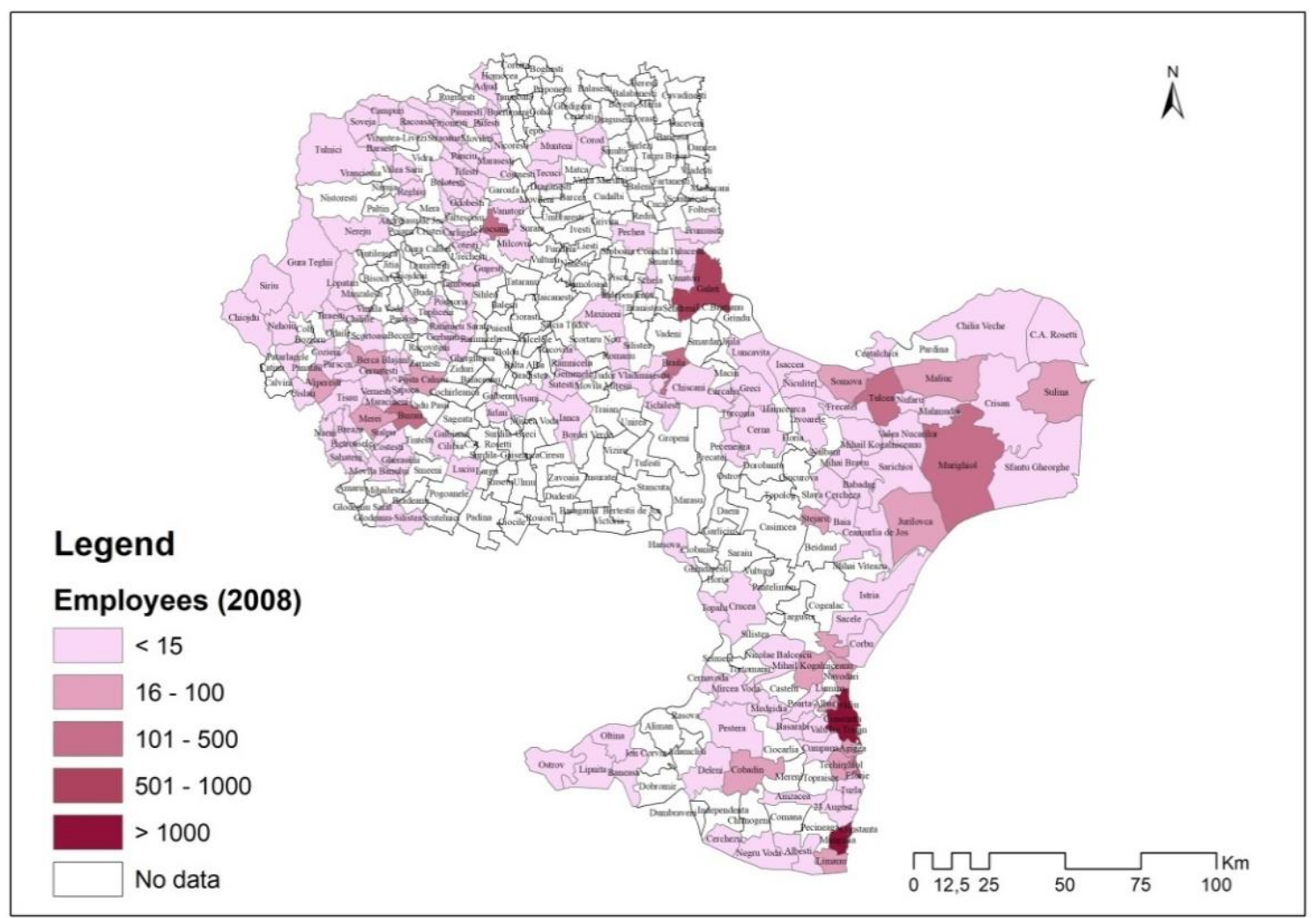

Figure 3. Distribution of the number of employees at the level of the South-East Development Region in 2008

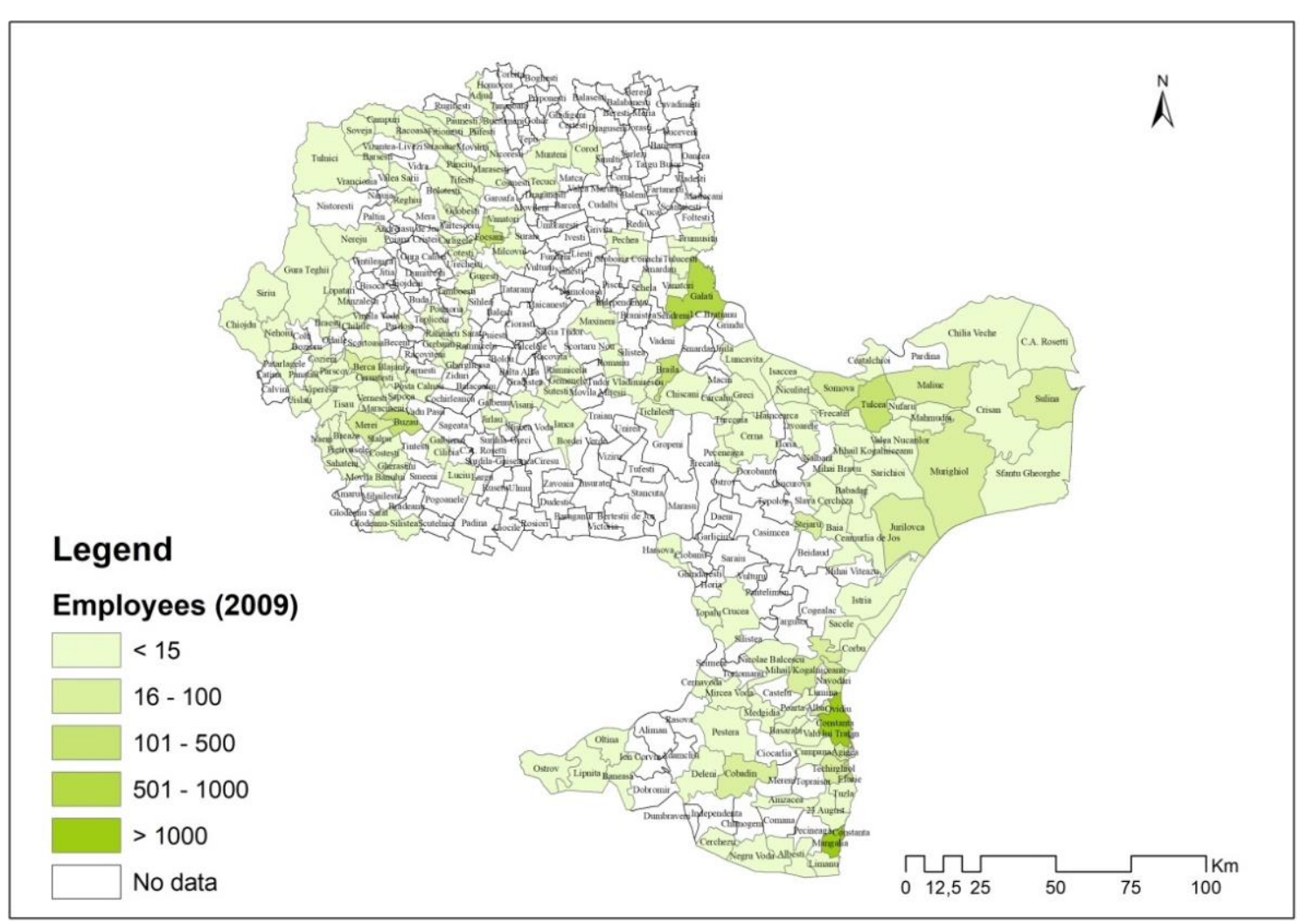

Figure 4. Distribution of the number of employees at the level of the South-East Development Region in 2009 
The year 2009 (Fig. 4) does not bring much change compared to the previous year, which shows that the economic crisis did not have a visible effect on this economic sector.

The number of territorial administrative units that do not register employees in tourism is $49 \%$ of the total area of the Danube Delta and the Black Sea coast, being among the territorial administrative units of Romania with a significant number of employees in tourism. Constanta and Mangalia remain the localities with the highest number of employees in tourism, the effects of the economic crisis not being visible.

At the level of 2016 (fig. 5), 46\% of the territorial administrative units did not register tourism employees. Further, the Black Sea coast and the Danube Delta are detached by the large number of territorial administrative units that registered significant values on the number of employees in tourism.

To these areas are added the mountainous and sub-Carpathian areas where tourism resources have stimulated the development of tourist activities and implicitly the increase of the number of employees in the field.

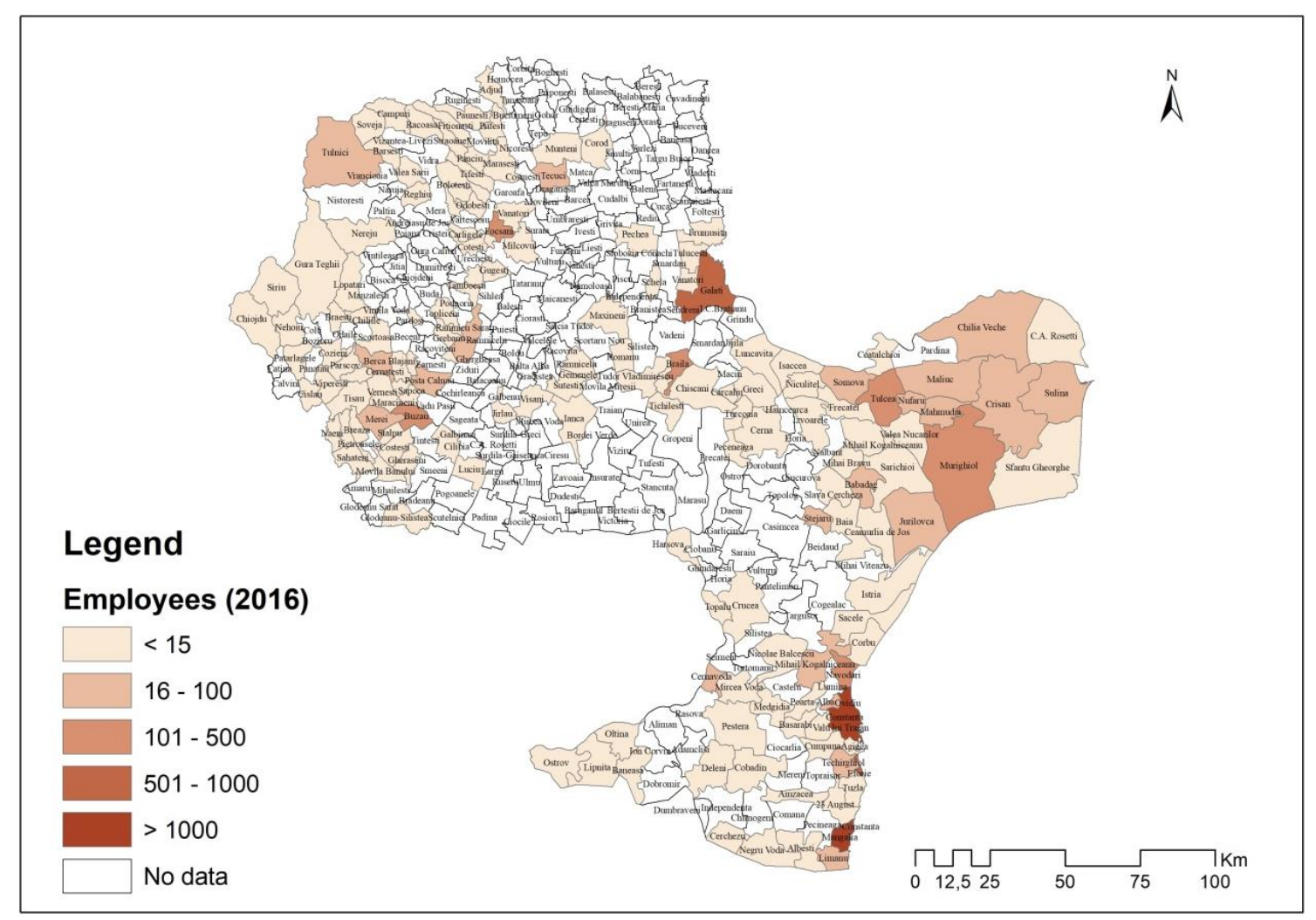

Figure 5. Distribution of the number of employees at the level of the South East Development Region in 2016

\section{CONCLUSIONS}

The interpretation of the cartographic models, in which the values corresponding to the number of employees in the tourist field in 2000, 2008, 2009 and 2016 in the South-East Development Region are presented, revealed the following:

- reducing the number of territorial administrative units that have not registered employees in tourism from $75 \%$ in 2000 to $46 \%$ in 2016 ;

- during the analyzed period, it is noted for the large number of employees, Constanta and Mangalia (over 1000 employees) 
- compared to 2000, within the South-East Development Region, the disparities in the number of employees in the tourism field in the territorial units of the Black Sea coastline have increased, while those corresponding to the area of the Danube Delta have registered a number in growth of employees.

Efficient management strategies can be a way to maximize the beneficial effects of the development of economic activities (implicitly those generated by tourism development) an essential condition being the in-depth knowledge of the particularities of the local economic system [11], [12], [13], [14], [15].

\section{REFERENCES}

[1] Strat V.A., Davidescu A.A.M, Grosu R.M \& Zgură I.D. A Quantitative Approach Regarding the Evolution of the Romanian Tourism Firms, During and After the Global Financial Crisis, Amfiteatru Economic, vol. 18, pp 815-828, 2016.

[2] Tyrrell T.J. \& Johnston R.J., An econometric analysis of the effects of tourism growth on municipal revenues and expenditure, Tourism Economics, vol. 15, pp 771-783, 2009.

[3] Pascariu G.C. \& Ibănescu B.C. Determinants and Implications of the Tourism Multiplier Effect in EU Economies. Towards a CorePeriphery Pattern?, Amfiteatru Economic, vol. 20, pp 982-997, 2018.

[4] Guido Ferrari, José Mondéjar Jiménez, Luca Secondi, Tourists' Expenditure in Tuscany and its impact on the regional economic system, Journal of Cleaner Production, vol 171, pp 14371446, 2018.

[5] Arionesei G., Hapenciuc C.-V. \& Costea M. Statistical Confrontation of the Evolution of Tourism in the North East Region in Comparison with the other Regions of Romania, Amfiteatru Economic, vol. 18, pp. 798-814, 2016.

[6] World Tourism Organization. Tourism for Development - Volume I: Key Areas for Action, UNWTO, Madrid, 2018, DOI: https://doi.org/10.18111/9789284419722.

[7] https://ec.europa.eu/eurostat/statistics-explained/index.php?title=Tourism_statistics

[8] Minciu R. Tourism grouth and its effects in the economy, Amfiteatru Economic, vol. 10, pp 271-276, 2008.

[9] Zopiatis A., Constanti P. \& Theocharous A.L. Job involvement, commitment, satisfaction and turnover: Evidence from hotel employees in Cyprus, Tourism Management, vol. 41, pp 129-140, 2014.

[10] http://statistici.insse.ro:8077/tempo-online/

[11] Peptenatu D., Merciu C., Merciu G., Drăghici C. \& Cercleux L. Specific features of environment risk management in emerging territorial structures, Carpathian Journal of Earth and Environmental Sciences, vol. 7, pp 135-143, 2012.

[12] Peptenatu D., Draghici D. \& Merciu C. Characteristics of entrepreneurial profile in some emergent territorial structures in Romania, Actual Problems of Economics, vol. 12, pp 448-458, 2012.

[13] Pintilii R. D., Peptenatu D., Ciobotaru A. M., Toma S. G., Grigore A. M., Drăghici C. C., Dobrea R. C., Simion A. G., Andronache I., Teodorescu C. \& Diaconu D. C. Creative economies in Romania - spatial projections and trends, Bulletin of Geography-Socio-Economic Series, vol. 37, pp 95-108, 2017.

[14] Drăghici C. C., Andronache I., Ahammer H., Peptenatu D., Pintilii R. D., Ciobotaru A. M., Simion A. G., Dobrea R. C., Diaconu D. C., Vișan M. C. \& Papuc R. M. Spatial evolution of forest areas in the northern Carpathian Mountains of Romania, Acta Montanistica Slovaca, vol. 22, pp 95-106, 2017.

[15] Braghină C., Peptenatu D., Drăghici C., Pintilii R. D. \& Schvab A. Territorial management within the systems affected by mining.case study the South-Western development region in Romania, Iranian Journal of Environmental Health Science \& Engineering, vol. 8, pp 315-324, 2011. 